\title{
A phonetic comparison of two Irish English varieties
}

\author{
Francesca Nicora ${ }^{1}$, Sonia Cenceschi ${ }^{2}$, Chiara Meluzzi ${ }^{3}$ \\ ${ }^{1}$ Department of Italian, National University of Ireland, Ireland \\ ${ }^{2}$ Department of Innovative Technologies, University of Applied Sciences of Southern \\ Switzerland \\ ${ }^{3}$ Department of Linguistics, University of Pavia, Italy \\ https://doi.org/10.36505/ExLing-2020/11/0035/000450
}

\begin{abstract}
This research offers a preliminary survey on vowels and diphthong variation between two Irish English varieties: Galway (GW) and Letterkenny (LK). The results showed only a smaller difference between GW and LK with respect to the monophthongs, whereas a larger difference was found for the MOUTH diphthong. Despite the great amount of literature on English dialects, a phonetic investigation of these specific varieties is still lacking. This study may open the path to further investigations of sociophonetic values-and the stereotypes associated with different varieties, in particular those of the northern regions.
\end{abstract}

Keywords: Irish English, sociophonetics, MOUTH, vowels, phonetics.

\section{Introduction}

The past years have witnessed an increasing number of studies focused on the phonology of Irish English (IE), shedding light on new tendencies in IE spoken across the present-day Republic of Ireland. For example, Hickey (2005, 2007) has discussed the IE realisation of the MOUTH diphthong / au:/ in eastern dialects, highlighting that in Dublin the realisation begins from a front starting point of [æ], which contrasts with the traditional IE low starting point of [av]. In present times, the rapid spread of new Dublin English across the country, especially among young females, is leading to a decrease of this feature that is traditionally associated with southern IE. On the other hand, previous research on the MOUTH diphthong showed that northern IE realisations differ from those in the south (Corrigan 2010). McCafferty (2007) specifically noted that no social or stylistic variation correlated to such variants were found while investigating the (London) Derry variety.

This research offers a preliminary survey on the cardinal vowels /a/ and /i/, and on the MOUTH diphthong variation across two IE varieties: Galway (GW) and Letterkenny $(\mathrm{LK})$ that belong respectively to southern IE and northern IE. LK is located in a transition zone between the south and north, called County Donegal - a part of the Republic of Ireland where IE is of a broadly northern type. To the authors' knowledge, an investigation of the variety spoken in LK is

ExLing 2020: Proceedings of $11^{\text {th }}$ International Conference of Experimental Linguistics, 12-14 October 2020, Athens, Greece 
still lacking, and the number of studies for the Galwegian variety is also very limited (Peters 2016). A phonetic investigation and comparison between these two varieties is therefore considered desirable so that new data can be compared with previous literature. Our hypothesis is that a difference between the GW and LK spoken varieties is present, but that the GW variety was more prone to supra-regional southern Irish English. Furthermore, we supposed that the diphthong will show a greater variation between the two varieties, and that a stylistic variation may also be present.

\section{Methodology}

The subjects of this research are two 22-year-old adult females born and currently living in GW and in LK, respectively. Speech materials were drawn from the corpus of Irish English Speech (IES), which was designed to gather data on spoken speech of different Irish English varieties in the present-day Republic of Ireland (Nicora 2020b). Recording sessions recorded in a soundproof room followed the guidelines of the Interactive Atlas of Romance Intonation (IARI) project (Prieto et al. 2011-2014), and were based on the Discourse Completion Task (DCT; Blum-Kulka et al. 1989). The DCT was translated into English and adapted for Irish speakers as detailed by Nicora (2020a). Two target words, "mandarins" and "tangerines", and three words containing the MOUTH diphthong were selected for the analysis of the cardinal vowels /a/ and /i/ and the diphthong /ou/ respectively.

\section{Analyses}

142 tokens were manually annotated in PRAAT for the cardinal vowels /a/ and /i/ in the words "mandarins" and "tangerines" and for the MOUTH diphthong in the sentence "It's too loud, turn down the sound". A script was used to automatically extract the F0, F1, F2 and F3 values at 7 target points (dynamic analysis). A quantitative analysis was conducted only on monophthongs, as the number of stimuli containing the MOUTH diphthong did not allow for a proper quantitative analysis. However, due to the perceived variation in MOUTH between our two target varieties, we decided to first investigate these data qualitatively, before pursuing further analysis.

We performed a one-way ANOVA analysis on the cardinal vowels' formants. Data shown in Tab. 1 indicates that there is a significant difference only in F1 for both values given at the midpoint. Specifically, the LK F2 is significantly lower for $/ \mathrm{a} /$ than in GW, with a mean difference of approximately $163 \mathrm{~Hz}$. Conversely, the first formant of /i/ is higher in LK than in GW. The ANOVAs show no significant results for /a/ F1, and for /i/ F2. 
Table 1. Mean values of $/ \mathrm{a} /$ and /i/ vowels in GW and LK, with Anova results.

\begin{tabular}{|c|c|c|c|c|c|}
\hline & Galway & Letterkenny & Anova & $\mathrm{p}$ value \\
\hline \multirow[t]{2}{*}{$/ \mathrm{a} /$} & F1 & $\begin{array}{l}995.12 \mathrm{~Hz} \\
\text { (st. dev. 20.84) }\end{array}$ & $\begin{array}{l}957.515 \mathrm{~Hz} \\
\text { (st. dev. } 52.29 \text { ) }\end{array}$ & $\mathrm{F}(1.51)=.652$ & $=.423$ \\
\hline & $\mathrm{F} 2$ & $\begin{array}{l}\text { 1827.126 Hz } \\
\text { (st. dev.) 17.31) }\end{array}$ & $\begin{array}{l}1663.85 \mathrm{~Hz} \\
\text { (st. dev. 23.52) }\end{array}$ & $F(1.51)=28.535$ & $<.0001 * * *$ \\
\hline \multirow[t]{2}{*}{ /i/ } & F1 & $\begin{array}{l}416.88 \mathrm{~Hz} \\
\text { (st. dev. 18.18) }\end{array}$ & $\begin{array}{l}482.8 \mathrm{~Hz} \\
\text { (st. dev. 19.89) }\end{array}$ & $\mathrm{F}(1.51)=5.039$ & $=.030^{*}$ \\
\hline & $\mathrm{F} 2$ & $\begin{array}{l}2493.83 \mathrm{~Hz} \\
\text { (st. dev. 15.09) }\end{array}$ & $\begin{array}{l}2295.38 \mathrm{~Hz} \\
\text { (st. dev. 10.61) }\end{array}$ & $\mathrm{F}(1.51)=12.02$ & $=.102$ \\
\hline
\end{tabular}

No significant variation has been found between read and spontaneous speech. As for the MOUTH diphthong, the audio analysis has been supported by the qualitative investigation of a PRAAT spectrogram. In GW the diphthong is realised as [ao], while in LK it was realised as [øy], but with great withinspeaker variation. In spontaneous speech, the diphthong in LK was reduced to a more centralized monophthong $[\Theta]$ for about a quarter of the corpus. This is reflected in the variation of the F1 and F2 mean values, as calculated at the second and sixth time point, thus corresponding to the first and second element of the diphthong (Tab. 2). As is clearly seen from the values in Tab. 2, the MOUTH diphthong has been realised differently between the two varieties. Although auditorily perceived as $[y]$, the second element of the diphthong also seems to differ between the two varieties, particularly concerning the F1, where we find lower values in LK than in GW.

Table 2. Mean values of the MOUTH diphthongs in GW and LK as measured at the second and sixth points in time.

\begin{tabular}{|c|c|c|c|c|}
\hline & \multicolumn{2}{|l|}{ Galway [av] } & \multicolumn{2}{|l|}{ Letterkenny [øу] } \\
\hline & $2^{\text {nd }}$ time point & $6^{\text {th }}$ time point & $2^{\text {nd }}$ time point & $6^{\text {th }}$ time point \\
\hline F1 & $\begin{array}{l}975.0 \mathrm{~Hz} \\
\text { (st. dev. 9.62) }\end{array}$ & $\begin{array}{l}962.25 \mathrm{~Hz} \\
\text { (st. dev. 7.84) }\end{array}$ & $\begin{array}{l}701.606 \mathrm{~Hz} \\
\text { (st. dev. 10.41) }\end{array}$ & $\begin{array}{l}513.918 \mathrm{~Hz} \\
\text { (st. dev. 11.03) }\end{array}$ \\
\hline $\mathrm{F} 2$ & $\begin{array}{l}\text { 1849.749 } \mathrm{Hz} \\
\text { (st. dev.) 13.79) }\end{array}$ & $\begin{array}{l}\text { 1665,048 Hz } \\
\text { (st. dev. 14.59) }\end{array}$ & $\begin{array}{l}1454.978 \mathrm{~Hz} \\
\text { (st. dev. 9.81) }\end{array}$ & $\begin{array}{l}1771,613 \mathrm{~Hz} \\
\text { (st. dev. 10.47) }\end{array}$ \\
\hline
\end{tabular}

\section{Discussion and conclusions}

This preliminary investigation highlights the similarities and differences between the two Irish English varieties spoken in GW and LK. The data shows a tendency towards a centralization of the cardinal vowels /a/ and /i/, qualitatively confirmed for the MOUTH diphthong, which was also at times realised as a monophthong $[\Theta]$ by the $\mathrm{LK}$ speaker. Both varieties maintain a low 
starting point, which differs from the attested fronting in Dublin English (Hickey 2007). Furthermore, a lack of stylistic difference between read and spontaneous speech in the realisation of cardinal vowels has been noticed.

These preliminary results need to be confirmed by the collection of a wider sample and further analysis of stylistic variation, particularly of the northern varieties of Irish English. Further studies will be also necessary to test whether and how native speakers perceived this variation, especially in the MOUTH diphthong, and if there are any social values specifically associated with its reduction into a monophthong. The work confirms and updates what we knew about Irish English, and it opens the path to further investigation into the possible stereotypes associated with northern versus southern varieties.

\section{Acknowledgements}

The article has been written jointly by the authors. For the needs of the Italian Academy, F. Nicora wrote the introduction and methodology, and C. Meluzzi the analysis, discussion and conclusion. F. Nicora is responsible for the data collection, S. Cenceschi for the automatic extraction of values, and C. Meluzzi for the data annotation and statistical analysis.

\section{References}

Blum-Kulka, S., et al. 1989. Investigating cross-cultural pragmatics: An introductory overview. Cross-cultural pragmatics: Requests and apologies, 31, pp.1-34.

Hickey, R. 2005. Dublin English: evolution and change. John Benjamins Publishing.

Hickey, R. 2007. Irish English: History and present-day forms. Cambridge University Press.

McCafferty, K. 2007. Northern Irish English. In Language in the British Isles, D. Britain, (ed.), 122-134. Cambridge: CUP.

Nicora, F. 2020a, Prosodic training in foreign language: a study with Hiberno English learners of Italian, $\mathrm{PhD}$ thesis, unpublished.

Nicora F. 2020b. The corpus of Irish English Speech (IES), IRAAL conference, submitted.

Peters, A. 2016. Linguistic change in Galway City English. A variationist study of (th) and $(\mathrm{dh})$ in urban western Irish English. Duisburg Papers on Research in Language and Culture, Vol.116. Frankfurt a.M.: Peter Lang.

Prieto, P., Borràs-Comes, J., Roseano, P. (Coords.) 2010-2014. Interactive Atlas of Romance Intonation. Web page: http://prosodia.upf.edu/iari/. 